RESEARCH ARTICLE

\title{
MOVEMENT CONTROL ORDER ON LEGAL AND SOCIAL ASPECTS: MALAYSIAN AND INDONESIAN GOVERNMENT INITIATIVES DURING COVID-19
}

\author{
Ahmad Zaharuddin Sani Ahmad Sabri ${ }^{1}$, Roziyah Abu ${ }^{2 凶}$ \\ Nicholas Khoo Kim Seng ${ }^{3}$, Rodiyah ${ }^{4}$ \\ ${ }^{1}$ School of Languages, Civilizations \& Philosophy, Universiti Utara Malaysia \\ ${ }^{2}$ Faculty of Information Management, Universiti Teknologi MARA, Malaysia \\ ${ }^{3}$ SOCIO intelligence Sdn. Bhd., Malaysia \\ ${ }^{4}$ Faculty of Law, Universitas Negeri Semarang, Indonesia \\ $\triangle$ roziyah307@uitm.edu.my
}

\section{CITED AS}

Sabri, A. Z. S. A., Abu, R., Seng, N. K. K., \& Rodiyah, R. (2020). Movement Control Order on Legal and Social Aspects: Malaysian and Indonesian Government Initiatives During Covid-19. Journal of Law and Legal Reform, 1(4), 563-576. https://doi.org/10.15294/jllr.vli4.38465

\section{ABSTRACT}

The Covid-19 pandemic hit another grim milestone on as worldwide deaths from the disease exceeded 100,000. Many countries have enforced social distancing rules and even lockdowns in an effort to contain the spread of the virus. Malaysian Government, in almost daily bases proposed initiatives and efforts to uphold Malaysia social, economic and national stability. This article deliberates an analysis on social media sentiment index by topics mentions in Malaysian government. The Malaysian government Covid19 major initiative discuss within this article is the proposition to reopening selected business sectors during Movement Control Order (MCO). This analysis was conducted using Social Media Engagement Growth components such as likes, comments and shares. The social media platform mentions in this study include all mentions or discussion of the initiatives across all public social media, Facebook, Twitter, Instagram, Forums, and blogs.

Keywords: MCO, Quarantine, Covid-19, Malaysia Government, online social network, MPI index 


\section{TABLE OF CONTENTS}

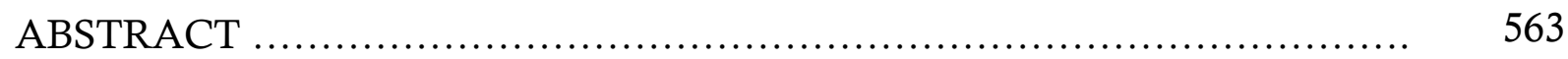

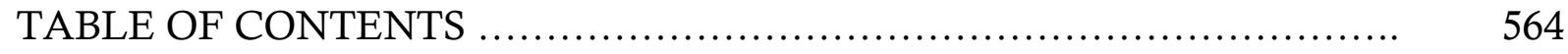

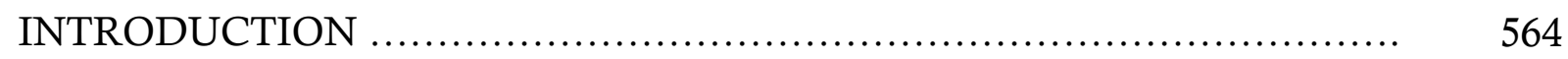

BACKGROUND STUDY: GOVERNMENT INITIATIVES DURING

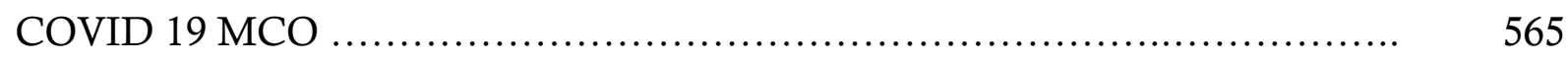

METHOD …........................................................... 567

MOVEMENT CONTROL ORDER ON SOCIAL AND LEGAL ASPECTS ... 568

I. DEVELOPMENT OF THE CASE IN MALAYSIA ........................... 568

II. SOCIAL AND LEGAL ASPECTS: CASE OF INDONESIA …............. 571

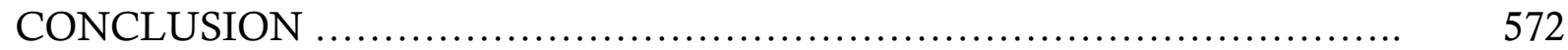

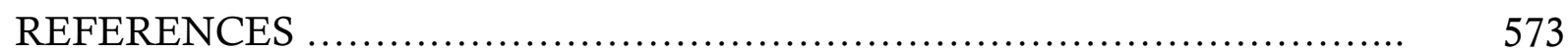

\section{INTRODUCTION}

The emergence of online social network has changed our traditional communication landscape and in the way we interact with each other. A major part of this change is the advent and evolution of online social networking media and sites on the Internet, which further lead to the formation of many virtual groups that communicate, share information, and even retain ongoing relationships. On-line social networking group chats, conversations and dialogue on Facebook, twitter, Instagram, WhatsApp, telegram and many more have become part of our daily life necessity. In short, these changes have brought a permanent change in the way we interact and socialize in daily basis.

Many studies (Zúñiga, Weeks \& Ardèvol-Abreu, 2017; Bode, 2016; Pew, 2016; Garrett et al., 2012), has proven that online social network platform have provide its users the opportunities to be exposed to information, incidentally and through content shared by others in their social networks. According to Homero Gil de Zúñiga, Brian Weeks and Alberto Ardèvol-Abreu (2017), this type of information exposure have made users to hold a mistaken perception that they are being wellinformed, for all the important updates about the subject matter will find them without their actively seeking it. Hence these type of online users further then makes instance conclusion and share their opinion actively online.

The Malaysians' Perception Index (MPI) is a social sentiment measurement used to analyse and indicate online social media conversations. MPI focusses on the 
organization, identification, and interpretation of sensory information in order to represent and understand the presented information or environment. This index is being introduce to allow an investigate to the perception acceptance among netizens, on online social media network platform in regards to Malaysian government initiatives and efforts in combating Covid-19.

\section{BACKGROUND STUDY: GOVERNMENT INITIATIVES DURING COVID $19 \mathrm{MCO}$}

In 18 March 2020, the lst phase of Malaysia Movement Control Order or MCO was implemented throughout the country. In Malaysia, MCO works as a barricade sanitaire preventive measure of the federal government of Malaysia towards the coronavirus pandemic. With current situation, Malaysia Coronavirus record cases, namely 5,182; with number of deaths recorded, 84 people; and recovered record cases are 2,766 (MOH, 16 April, 2020), the 3rd phase (15 - 28 April 2020) of MCO is now being implemented.

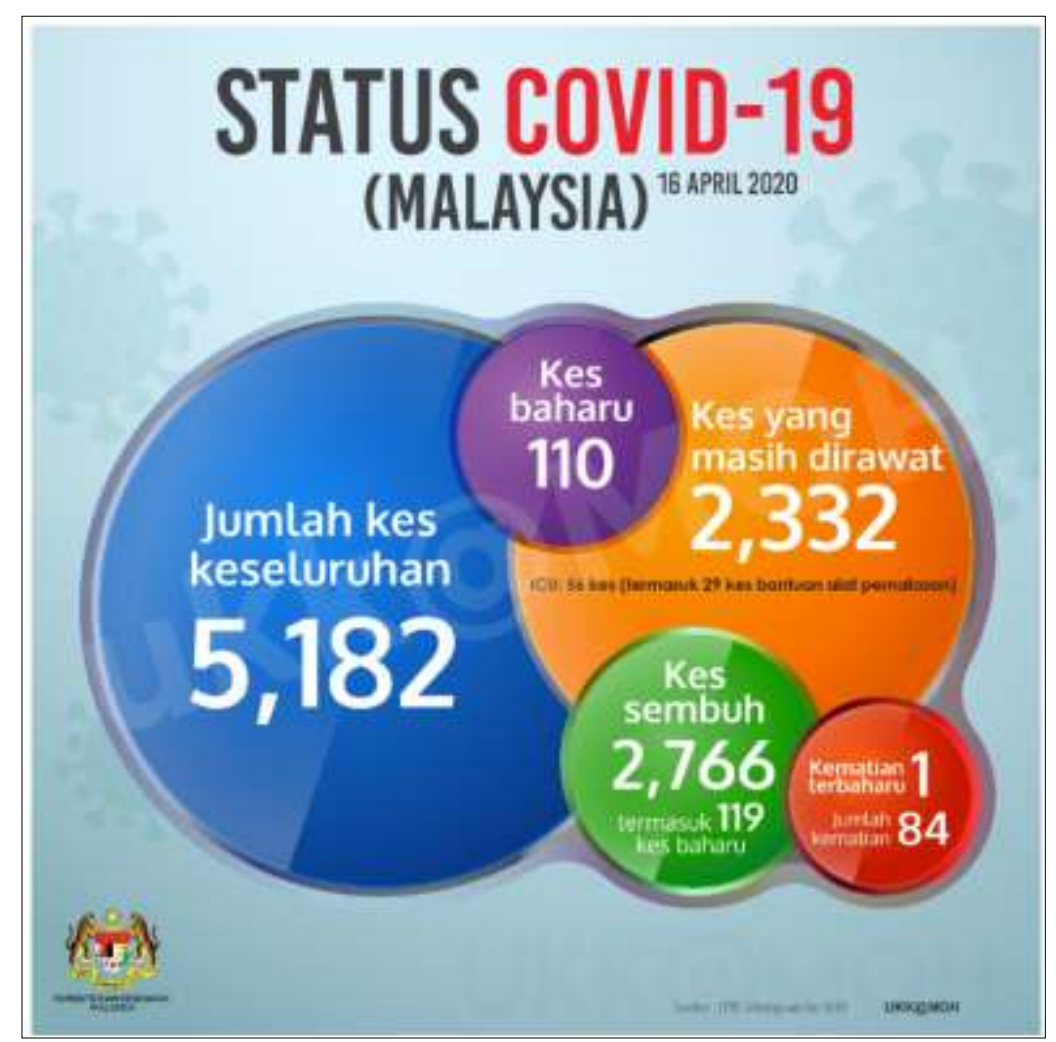

Figure 1 Infographic Malaysia Coronavirus record cases by MOH from http://www.moh.gov.my/index.php/pages/view/2019-ncov-wuhan 
During the MCO from 18 March 2020 - 28 April 2020, Malaysian are prohibited of any form of mass movements and gatherings across the country including religious, sports, social and cultural activities. Meaning all houses of worship and business premises are closed, except for essential-industry and essential services such as supermarkets, public markets, grocery stores and convenience stores selling everyday necessities, also water, electricity, energy, telecommunications, postal, transportation, irrigation, oil, gas, fuel, lubricants, broadcasting, finance, banking, health, pharmacy, fire, prison, port, airport, safety, defence, cleaning, retail and food supply. Other closure includes all kindergartens, government and private schools, all public and private higher education institutions (IPTs) and skills training institutes nationwide. All travelling abroad are now being unauthorized. Meanwhile for those who have just returned from overseas, they are mandatory to undergo a health check and to do a quarantine (or self-quarantine) for 14 days. Plus, MCO in Malaysia practices a very restricted entry procedure to all tourists and foreign visitors.

It is believed that MCO action has contributed to the progress of the current, Malaysian fight against Covid-19. According to Malaysia Health Director-General Datuk Dr Noor Hisham Abdullah, Phase 3 of the MCO, is the most important phase of all, not just because it signifies that Malaysia is in the recovery phase, but because it will allow Malaysia to recover.

\section{"If we succeed in doing so, it is possible for us to reduce the case, not only to flatten the curve but also to end the spread of the COVID-19 outbreak in the country," (Malaysia Health Director-General Datuk Dr Noor Hisham Abdullah, Astro Awani, 2020)}

In line to the MCO, the number of Malaysian social media users have showing sudden rapid escalation. Telekom Malaysia Berhad (TM) (The Star, April 3, 2020) said it is seeing more than a 30\% increase in usage trending, and of this, the increase of international link traffic was 5\%. Meanwhile, The Malaysian Reserve (Wednesday, April 15th, 2020) reported that the pressure on Internet infrastructure is currently being felt in countries facing high number of cases, including Malaysia, Italy, and Spain. Within the period of MCO in Malaysia, uses for the Internet by different industries including entertainment, education and shopping has shown a rapid escalation including in home-based entertainment, video conference and online communication. Similarly, due to the decreasing options personal face to face communication, people are beginning to share and expressing their thought, emotion 
and idea online too. In 2017, 25.3 million people were accessing the internet in Malaysia and this figure is projected to grow to 29.4 million in 2023 (Statista, 2020 (a)). In 2023, it is estimated that there will be around 26.1 million social network users in the country, up from 22.7 million in 2017.

In 20111 a study done Daria J. Kuss and Mark D. Griffiths (2011) has shown that massive dependency on online social network leads to addictive behaviour and as a result, users may spend an increasing amount of time on these virtual sites without realizing the associated negative effects (Kuss \& Griffiths, $2011 \& 2017$ ). In Malaysia, during MCO there's an alarming increasing number and percentage usage of online social network platform. According to Corporate News (the Star April 2020), there is a sequential traffic surged between $190 \%$ and $250 \%$ during the rolling seven-day period in the third week of March (MCO phase two) for online media platforms. This alarming progress worries many, for prior research in psychology discipline have contently suggests that online media networking addiction can distorts one's perceptions (Thadani \& Cheung, 2011).

Therefore, this study aims to investigate the perception acceptance among netizens, on online social media network platform - Social media user's perception; in regards to Malaysian government initiatives and efforts in combating Covid19. This study objective is to share the findings of netizen emotional perception, focuses on government initiatives to reopening selected business sectors during MCO.

\section{METHOD}

This is a study on the social media sentiment index by topics mentions in Malaysia Covid19 phenomena. The Malaysians' Perception Index (MPI) is the social sentiment measurement used to analyze and indicate social media conversations. The measurement starts from $100 \%$ to $1 \%$ for positive, 0 for neutral and $-1 \%$ to $-100 \%$ for negative. The formula used in this analysis are:

(the no. of positives - no. of negatives) / (total no. of positives and negatives) $x 100$

Hence, if more positive mentions establish than negative mentions, then the MPI (sentiment) will be positive. 
Meanwhile, social media platform mentions in this study include all mentions or discussion of the topic across all public social media, Facebook, Twitter, Instagram, Forums, blogs, etc. This analysis was conducted on the 13 April 2020 with 373K mentions and 16 April 2020 with 510K mentions documented with focuses on government initiatives to reopening selected business sectors during MCO.

\section{MOVEMENT CONTROL ORDER ON SOCIAL AND LEGAL ASPECTS}

\section{DEVELOPMENT OF THE CASE IN MALAYSIA}

On 13 April 2020, Malaysia government through its Ministry of International Trade and Industry Ministry (MITI), has put forward an initiative to reopening selected business sectors during MCO. Within this initiatives, the Malaysia Minister of International Trade and Industry Ministry (MITI), YB Dato' Seri Mohamed Azmin bin Ali, decision to allow several selector sectors such as barbershop to operate during

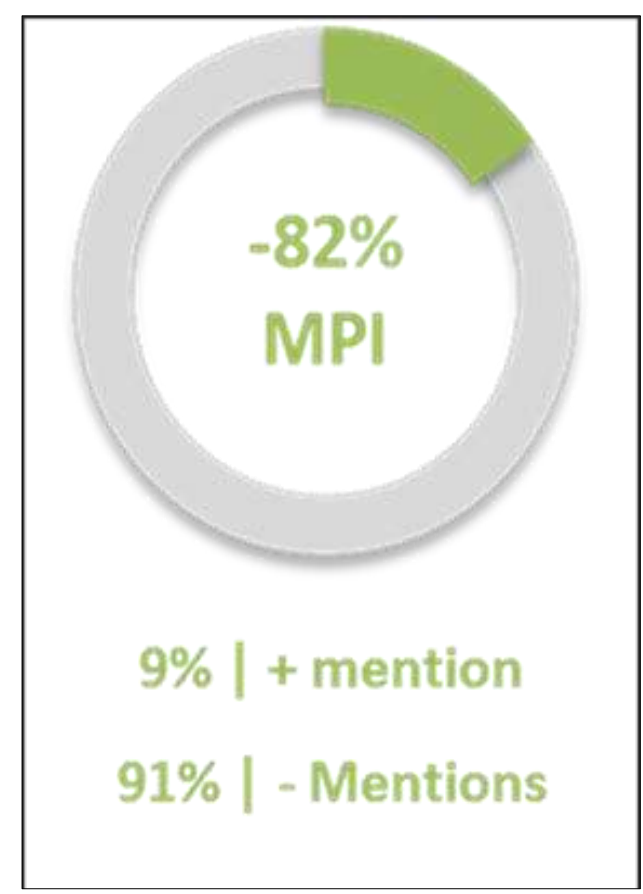

Figure 2: 13 April 2020 Online Social Network Response on reopening Selected Sector during MCO
MCO was rejected. $91 \%$ online social network users' negative mentions highlights disagreement with the decision. Many online users claimed that this decision will undermine the main objective of the MCO and it will increase the risk of spreading the virus. In specific, netizens rejected the government's decision to allow barbershop to operate as it is not part of the essential-industry. Furthermore, netizens criticized MITI for making a decision without proper discussion with Ministry of Health $(\mathrm{MOH})$.

However, a small percentage of mentions agreed with the initiatives namely $9 \%$, for it is believe that this initiative will stimulates Malaysian economy. Nonetheless, netizens complained about not being able to access MITI's website to apply to reopen businesses.

Within 373K mentions in 13 April 2020; $33,570(9 \%)$ positive mentions and 339,430 (91\%) negative mentions. Hence, since more negative 
mentions establish within this topic than positive mentions, then the MPI (sentiment) is negative, namely - $82 \%$.

On the 16 April 2020, during the online live telecast of the initiatives clarification Press conference made by the Malaysia Minister of International Trade and Industry Ministry (MITI), YB Dato' Seri Mohamed Azmin bin Ali, three main online mediums were used namely 1) Harian Metro ${ }^{1}$ (online Live) with 522K viewers, 2) Berita Harian ${ }^{2}$ (online live), with $523 \mathrm{~K}$ viewers and 3) MITI Ministers Facebook (online live), $2.3 \mathrm{~K}$ viewers.

Data shows that during the online live telecast of the initiatives clarification Press conference made by the Malaysia Minister of International Trade and Industry Ministry (MITI), YB Dato' Seri Mohamed Azmin bin Ali, an accumulation of 15,316K likes from the total of $1,047,300 \mathrm{M}$ views which is equivalence to only $1.4 \%$ likes of the views. Meanwhile an accumulation of 2,065K shares from the total of $1,047,300 \mathrm{M}$ views which is equivalence to only $0.2 \%$ shares of the views.

The key insight on the social media engagement growth shows positive praises upon YB Dato' Seri Azmin Ali for addressing concerns about MITI allowing some sectors to resume operations during MCO. Others supported the decision as it is important to sustain Malaysia's economic plans. And on the neutral part, there's inquiries on the status of their personal sector (owner of businesses and company) to operate and the details of Standard Operating Procedures (SOP) with the Covid-19 testing and sanitisation.

1 Harian Metro online live is a live streaming videos and television news which are provided via streaming television or via streaming media by Harian Metro news networks which own by the New Straits Times Press (M) Bhd. as part of Media Prima Group.

2 Berita Harian (BH) online live BH is a Malay-languaged daily newspaper published in Malaysia owned by the New Straits Times Press. It was first published on 1 July 1957 as the first mainstream newspaper in Malaysia. 


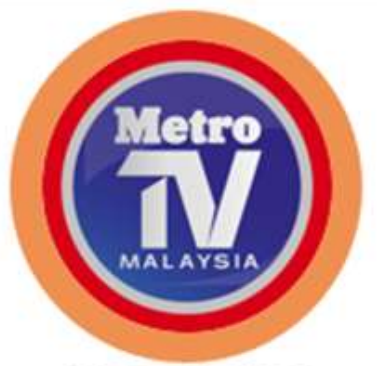

16 April 2020

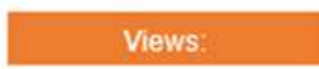

$522 \mathrm{~K}$

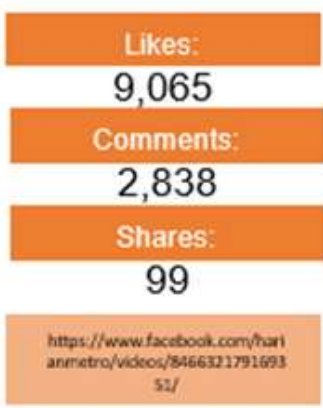

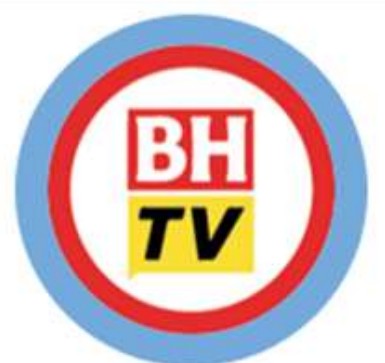

16 April 2020

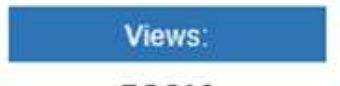

$523 K$

\begin{tabular}{|c|}
\hline Likes: \\
\hline 4,545 \\
\hline Comments: \\
\hline 370 \\
\hline Shares: \\
\hline 1,686 \\
\hline 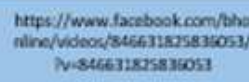 \\
\hline
\end{tabular}

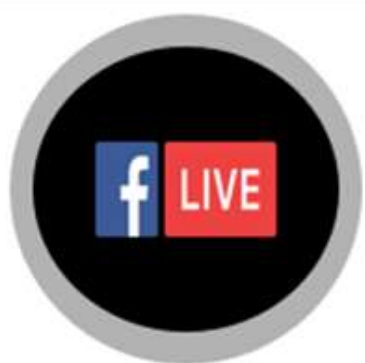

16 April 2020

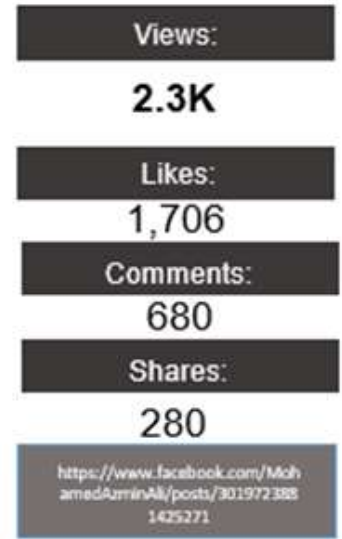

Figure 3: Figure 2: 16 April 2020 Live Streaming Press Conference Online Social Network Response on reopening Selected Sector during MCO

Conversely, many condemned and blamed MITI for the high traffic during the start of MCO Phase 3 (which starts on the 15 April 2020 - a day after the announcement of the reopening selected business sectors during MCO) recently. netizen expressed their concerns that the reopening of certain sector industries will fail the MCO goals. Hence many netizens were disappointed that MITI's decision was not consistent with the Ministry of Health; emphasizing that the MCO Phase 3 is crucial to mitigate the epidemic. Below are some of the responses recorded.

Should wait for Covid to be under control, only then allow businesses to start. Every day we found more than a hundred new cases it is not wise to allow business to open now. (Respond Harian Metro Online: Syafiqah Azman)

Why not help the efforts to prevent the corona virus from spreading ... everyone wants to operate now... government's 


\section{efforts with MCO will be a loss (Respond Berita Harian Online: Mazlina Sam).}

The netizens sarcastically questioned the supervision enforcement for the industry, highlighting that many companies failed to follow the current legislation especially those with illegal immigrant's workers. Others also demanded stricter punishment to businesses and companies that fail to follow the regulations set by MITI. In addition, they claim that staff screening would consume time and that the Standard Operating Procedures (SOP) would allow the government to take advantage of the Covid-19 testers and applicants.

All and all, netizens expressed their concerned about the effectiveness of procedures requested by MITI. With positive sentiment of only $7 \%$ and negative sentiment 93\%, the Malaysians' Perception Index (MPI) within the the social sentiment measurement used to analyze and indicate social media conversations on the reopening selected business sectors initiatives during MCO is negative $-86 \%$.

With reference to all responds, criticisms, and concern, MITI has run more press conferences with the intention to clarifies the situation and enrich their SOP explanation to Malaysia through more online social network live telecast.

\section{SOCIAL AND LEGAL ASPECTS: CASE OF INDONESIA}

Since Covid-19 cases have increased in Indonesia, various social and economic problems have emerged in society. It is undeniable that Covid-19 has almost paralyzed the socio-economic conditions of the Indonesian people, especially in some areas with the highest distribution rates such as Jabodetabek. As of April 1, 2020, the total number of positive patients for Covid-19 in Indonesia has reached 1,677 people. Of the 1,677 positive cases of Covid-19, 1,417 patients are currently undergoing treatment and 103 patients have successfully recovered from Covid-19 (Tirto, 1 April 2020). Meanwhile, Indonesian citizens abroad have also been affected by Corona with a total of 133 Indonesian citizens who were positively infected with Covid-19 (Tirto, March 31, 2020).

As a result of the Corona case, the Indonesian government began to carry out various policies such as issuing social distancing calls, issuing appeals for Work From Home for employees, imposing territorial restrictions, building special hospitals for handling Covid-19, and others. With the existence of this government policy and the increasingly precarious situation, of course it will have an impact on society, both the 
middle to lower class and the elite. Various socio-economic problems arise and the impact is immediately felt by the community.

The social problem itself is a mismatch between elements of culture or society that endangers the life of the social group or hinders the fulfillment of the basic desires of the members of the social group, causing social ties to be lame (Soekanto, 2013). Social problems arise from deficiencies in humans or social groups that originate from economic, biological, biopsychological, and cultural factors. Increasingly, the socioeconomic problems caused by Covid-19 are increasingly visible to the community. Some of the socio-economic problems that have occurred due to Covid-19 as emphasized by Alifa (2020), include:

First, Scarcity of goods, that since the number of Covid-19 victims continues to increase in Indonesia, several items have become scarce on the market. Not only rare, but these items were sold many times their original price before the Corona case in Indonesia. Some items that are becoming scarce include masks, hand sanitizers, disinfectants, and PPE. These goods are now being sold at a much higher price than their original price. This is in accordance with the law of economics where when demand increases but goods are getting low, the price will increase. Even people with middle and upper economic conditions have a tendency to buy up these goods so that there is an accumulation of goods but for the middle to lower class people they cannot get them.

Not only for personal protective equipment, people also flock to buy basic necessities in large quantities, along with the issue of lockdown in Indonesia. Hoarding of goods as a result of something emergency is called panic buying. Executive Director of the Institute for Development of Economics and Finance (INDEF) Enny Sri Hartanti said that panic buying behavior is caused by psychological factors due to imperfect or comprehensive information received by the public (Tirto, March 25, 2020). The lack of this information caused the public to panic, so they responded by spending massively in an effort to save themselves. The public's concern is that they are worried that prices will rise if they do not shop immediately and worry that goods will run out soon.

Second, Social disorganization and dysfunction, that if we look at the news circulating lately, there are interesting social facts that occur in society. This interesting fact is the existence of prejudice and discrimination against Covid-19 victims. This prejudice and discrimination is caused by people's fear of uncertain situations due to the spread of the Corona virus. This can be seen clearly from the attitude of the community who keeps their distance when interacting with others, avoids shaking hands, avoids gatherings, and so on. This attitude of society originates 
from prejudice which leads to discriminatory attitudes. This prejudice and discrimination is a manifestation and social disorganization (Syaifudin, 2020).

Third, Criminal Actions which it is feared that the Covid-19 problem will have an impact on an increase in criminal activity. The criminal acts committed can be various, such as theft of personal protective equipment which is currently scarce, making fake hand sanitizers or disinfectants that actually endanger health, fraud in the price of basic goods, and others. One example is the case of a civil servant in Cianjur who was caught stealing 20,000 masks (Kompas, 26 March 2020). Other larger crimes such as robbery, murder, looting, might have occurred if the situation got out of hand.

\section{CONCLUSION}

Malaysia in going through a rough road into the future. In fact, all over the world, everyone is facing tough time ahead. Due to tise current circumstances, Malaysian online social networks tools have become the most popular method for netizen to communicate with each other, especially while dealing with MCO and pandemic war. According to statistic, as of January 2020, about 81 percent of the Malaysian population are active social media users (Statista, 2020 (b)). Many Malaysian turn to social networks for relevant information, to communicate, to work, to learn, to express our emotion even our frustration and currently we as a society are practically living in a virtual life on social media beside our real lives at home.

As a multicultural and multi religion country, it is also important for the netizen to be provided with information and FAQs about government initiatives and its impact to all level of group beneficiaries in many languages on all media channels for reference and people's guidance. But most importantly, Malaysian must be guarded against all form of SMS texting, WhatsApp messaging and its links received on all form of government assistance initiatives to prevent fraud by a scammer.

But predominantly, online social network users aka netizen, must practice selfconstrain (Bermúdez, 2016). We must exercise smart and humble usage of words. Control emotion while expressing one feeling and frustration online. Take some time to review our postings and consider whether all the things we posted were necessary. We can also determine how much time we spend by tracking your usage. Take a break from your social media for time to time and assess how you feel. 


\section{REFERENCES}

Alifa, S. (2020). "Menganalisa Masalah Sosial Ekonomi Masyarakat Terdampak Covid-19", Article Online Pusat Penyuluhan Sosial Kemensos, retrieved from https://puspensos.kemsos.go.id/menganalisa-masalah-sosial-ekonomimasyarakat-terdampak-covid-19

Bermúdez, J. B. (2016). Social media and self-control: The vices and virtues of attention. Social Media and Your Brain: Web-Based Communication Is Changing How We Think and Express Ourselves. Editors: C. G. Prado. Praeger

Bode, L., (2016). Political news in the news feed: Learning politics from social media. Mass Communication \& Society, 19(1), 24-48. https://doi.org/10.1080/15205436.1045149

Garret, K., Bimber, B., Gil de Zúñiga, H., Heinderyckx, F., Kelly, J. \& Smith, M. (2012). New ICTs and the study of political communication. International Journal of Communication 6, 214-231

Kompas, 26 March 2020. Parah! 20.000 Masker di RSUD Pagelaran Cianjur Dicuri 3 Pegawai, CCTV Dimatikan Sebelum Beraksi. Retrieved from dari https://www.kompas.tv/article/73179/20-000-masker-di-rsud-pagelarancianjur-ternyata-dicuri-3-pegawai-cctv-dimatikan-sebelum-beraksi

Kuss, D. J., \& Griffiths, M.D. (2011), Online Social Networking and Addiction-A Review of the Psychological Literature. Int J Environ Res Public Health, 8(9): 35283552. Published online 2011 Aug 29. doi: 10.3390/ijerph8093528, PMCID: PMC3194102

Kuss, D.J., \& Griffiths, M.D. (2017), Social Networking Sites and Addiction: Ten Lessons Learned. Int J Environ Res Public Health, 14(3): 311. doi: 10.3390/ijerphl403031l. PMCID: PMC5369147

MOH (16 April 2020) Statistik terkini COVID-19 di Malaysia setakat jam 5:00 petang yang dikeluarkan oleh KKM (16 April) http://www.moh.gov.my/index.php/pages/view/2019-ncov-wuhan

Pew Research Center (2016, 7 July). The modern news consumer: News attitudes and practices in the digital era. Retrieved from http://www.journalism.org/2016/07/07/the-modern-news-consumer/ 
Salih, A.A.A., \& Elsaid, A.S. (2018). Students Attitude Towards the Use of Social Media for Learning Purposes. Journal of Literature, Languages and Linguistics. Vol. 50, 2018. ISSN 2422-8435

Soekanto, S. (2013). Sosiologi Suatu Pengantar. Jakarta: PT. RajaGrafindo Persada.

Socio Intelligence. (2020). MALAYSIANS' PERCEPTION REPORT: Government and Public Sector, Airline and Telecommunication Industry - 13 APRIL 2020 https://covid19.socio.com.my/

Statista 2020 (a), Malaysia: number of internet users 2017-2023 https://www.statista.com/statistics/553752/number-of-internet-users-inmalaysia/

Statista 2020 (b), Active social media users as percentage of the total population in $\begin{array}{llll}\text { Malaysia from } 2016 & 2020 .\end{array}$ https://www.statista.com/statistics/883712/malaysia-social-media-penetration/

Syaifudin, S. (2020). "Wabah Virus Corona dan Dampak Sosiologis”, Online, Tempo.co 3 March 2020. Retrieved from dari https://kolom.tempo.co/read/1314927/wabahvirus-corona-dan-masalah-sosiologis

Tirto, 25 March 2020. "Yuk, Kolaborasi Lawan COVID-19 untuk Atasi Dampak Ekonomi", Online, retrieved from dari https://tirto.id/yuk-kolaborasi-lawancovid-19-untuk-atasi-dampak-ekonomi-eHzg

Tirto, 31 March 2020.” WNI Positif COVID-19 di Luar Negeri Capai 133 Kasus, 3 Meninggal", Online, retrieved from dari https://tirto.id/wni-positif-covid-19-diluar-negeri-capai-133-kasus-3-meninggal-eJXr

Tirto, 1 April 2020. "Update Corona 1 April: Sebaran 1.677 Kasus di 32 Provinsi Indonesia", Online, retrieved from dari https://irto.id/update-corona-l-aprilsebaran-1677-kasus-di-32-provinsi-indonesia-eKdu

Thadani, D. R., \& Cheung, C. M. K. (2011), Exploring the Role of Online Social Network Dependency In Habit Formation. Thirty Second International Conference on Information Systems, Shanghai 2011. https://pdfs.semanticscholar.org/08c8/840587263e87b8478c84fd72bff5b096b7de .pdf

The Malaysia Reserves, Wednesday, April 15th, 2020 Malaysians turn to social media, streaming services to fill time during MCO, 
https:/themalaysianreserve.com/2020/04/06/malaysians-turn-to-social-mediastreaming-services-to-fill-time-during-mco/

The Star, Friday, 03 Apr 2020 Surge in data traffic for telcos during MCO https://www.thestar.com.my/business/business-news/2020/04/03/surge-indata-traffic-for-telcos-during-mco

The Star, Wednesday, 15 Apr 2020, Day 29: MCO enters its third phase today (April 15), https:/www.thestar.com.my/news/nation/2020/04/15/day-29-mco-entersits-third-phase-today-april-15

Tempo, 18 March 2020. "Sri Mulyani Ingin Stimulus Corona Sentuh Rakyat Kecil", Online, retrieved from dari https://bisnis.tempo.co/read/1321168/sri-mulyaniingin-stimulus-corona-sentuh-rakyat-kecil/full\&\&view=ok

Zúñiga H Gil de, Weeks B. \& Ardèvol-Abreu A. (2017) Effects of the News-Finds-Me Perception in Communication: Social Media Use Implications for News Seeking and Learning About Politics. Journal of Computer-Mediated Communication, 22(2017), $105-123$. 